\title{
Re-enter the United Nations: A Role for the Peacebuilding Commission in East Timor?
}

\author{
Geoffrey C. Gunn \\ Faculty of Economics, \\ Nagasaki University, \\ Japan
}

On 23 June 2006 the UN proudly launched its Peacebuilding Commission (PBC) seeking to reverse a situation where international efforts to rebuild war-torn societies had, more often than not, failed. In the words of its charter, the PBC will "marshal resources at the disposal of the international community to advise and propose integrated strategies for post-conflict recovery, focusing attention upon reconstruction, institution-building, and sustainable development in countries emerging from conflict.” As an advisory body made up of 31 member countries including four permanent members of the Security Council, and currently chaired by Japan, the PBC purports to offer tailormade solutions to target countries making the transition from war to peace.

Mindful of such cases as Haiti, Cambodia, Somalia, and Liberia, where security deteriorated once international support was withdrawn, obviously the drafters of the PBC had much to learn from the East Timor (Timor-Leste) example, just as they have much to contribute to the rehabilitation of the newly independent nation. This was highlighted by the massive civil unrest sparked off in East Timor in early 2006, returning to world attention in February 2008 with the near assassination of the Democratic Republic of Timor-Leste (RDTL) president and the continuing humanitarian crisis 
whose multiple dimensions are well addressed in the International Crisis Group’s report entitled “Timor-Leste's Displacement Crisis.” [1] The irony could not be lost on Timor-Leste that one of the PBC's specific briefs is to "extend the period of attention by the international community to post-conflict recovery.” [2] Initially, only Burundi and Sierra Leone came under the purview of the PCB, although emergency funding had also been advanced to Cote d' Ivoire and the Central African Republic. In December 2007, following a request from the government of Guinea-Bissau, and backed by Brazil, that country became the third to win PBC support as a state in danger of backsliding into violence. Given the ad hoc nature of past UN missions in East Timor/Timor-Leste, the hybrid character of security operations conducted independent of the UN flag, and the general lack of governance capacity inside the new nation, this article explicitly argues in favor of extending PBC commitment to Timor-Leste. [3]

\section{Background}

Born out of a 24-year guerrilla struggle (1976-1999) against Indonesian occupation, and an essentially Western-backed humanitarian intervention in the wake of the Indonesian military-militia violence following the UN-conducted ballot for independence in 1999, and surviving on a lifeline of international goodwill through independence from UN rule in May 2002, and again following wrenching internal violence commencing in mid-2006, the former Portuguese half-island Southeast Asian colony of East Timor has faced hard choices in meeting regional challenges. In part, this is a reference to relations with Muslim-majority Indonesia and, in part, reference to Australia, a major aid donor and contributor to its small northern neighbor in the security sector, but also a country that has played hardball in the negotiation of contested maritime boundaries and in the sharing of oil and gas revenues, crucial for the new nation's survival. 
Since attaining independence on 20 May 2002 under the popularly elected Fretilin government, the fledgling state of Timor-Leste has offered two sides to the international community. Here was an example of successful United Nations stewardship and transfer of ownership as exemplified by the United Nations Transitional Administration for East Timor (UNTAET) mission. In its time the Timor-Leste model had even been touted as a template to be applied to a number of other situations including Afghanistan. Besides coming under the scrutiny of the founders of the PBC, the Timor-Leste case entered a number of UN planning documents and discussions.[4]

With good reason, the UN was careful to craft a successor mission, the United Nations Support Mission in East Timor (UNMISET), especially with a view to building capacity in the new nation’s fledgling administration. Even so, special concerns remained over the security sector, including the induction and training of a Timor-Leste armed forces, Falintil-Forcas Defencas Timor-Leste (F-FDTL), and a TimorLeste police force, Policia Nacional de Timor-Leste, (PNTL). The fragility of the security situation was also underscored by a series of destabilizing events, including a virtual coup attempt in Dili on 4 December 2002. Not only did this affair, which saw an attack on the Prime Minister's residence, reveal the weakness of the PNTL in crowd control, but also pointed up the ambiguity in the UNMISET mandate over security alongside the independent state. In April 2005 a Catholic church-based confrontation also presented the government with a serious crisis. Continuing through 2006 various isolated security incidents in the countryside by disgruntled elements, including former anti-Indonesia resistance veterans, ex-pro-Indonesia militia and messianic-linked movements also disrupted the peace. Despite pledges by the world body to bring to book the perpetrators of crimes against humanity inside East Timor - notably a slew of Indonesian generals - such as eventually ruled by a UN-backed Special Crimes Court in Dili, weaknesses in the justice 
sector, as explained below, have actually helped to sow a culture of impunity where murder, arson and other heinous crimes go virtually unpunished. [5]

With the administration and UN agencies as the largest employer of waged labor the economic prospects of youth drawn to Dili from all the districts remained grim just as the new nation commanded the lowest per capita GDP in the region. Left to struggle under pro-market World Bank priorities, agriculture - the traditional employer in Timor-Leste - remained highly susceptible to the vagaries of the El Nino effect and the perennial cycle of floods and droughts, leaving many peasant households on the brink of starvation. By 2003-2004, just as Timor-Leste began to command oil revenues generated from the Timor Sea, so the Fretilin government operated a budget surplus. But with little experience at project management budgets characteristically remained unspent just as job generation failed to kick off. Political risk, bureaucratic obstacles, and a rising culture of patronage, corruption and crime which began to surface inside and outside of a number of departments and ministries dampens the enthusiasm of all but the most adventurous or opportunist foreign investors, just as the malaise saps the efficiency of the government. [6]

While the World Bank and the international community lavished praise upon the Fretilin government for its prudence in establishing a Petroleum Fund modeled along the lines of that of Norway, whereby only interest would be deducted from an escrew account deposited in New York, leaving the balance for future generations, few in the street could comprehend this logic. More than that, as a number of analysts have highlighted, the haste on the part of the international community to foist international models of governance upon a "subsistence state” was bound to fail, given the depth of tradition, the prevalence of custom law typical of "Melanesian"-type societies such as on Timor island, the lack of a bureaucratic state tradition such as found in neighboring Southeast 
Asian states, and the historical failure of Portuguese, Japanese and Indonesian occupiers to bequeath an embedded civil service tradition. [7]

\section{Crisis of 2006 Revisited}

Much hubris can be attached to the act of some 400 F-FDTL deserters who demonstrated in Dili on 8 February 2006 demanding a response to their January petition alleging regional discrimination. They were joined on 25 February by an additional 177 deserters, rising to 591 (or some 40 percent of the total) by mid-March. At this point, evidently following UN advice, the deserters were dismissed by the commander of the armed forces with the backing of the Prime Minister. But far from being disarmed and arrested, the "Petitioner” group around their spokesperson Major Gastão Salsinha, Major August Tara de Araujo, and Major Marcos Tilman joined on 4 May by Australiantrained Major Alfredo Alves Reinado emerged as actors in their own right, creating the seeds of the disaster-to-come. From their mountain bases above Dili, they rallied rural and urban supporters, built alliances and, in the case of Reinado, even courted President Gusmão and Foreign Minister Ramos-Horta, who made his first contact with the renegade leader and his military police deserters on 12 May, a prelude of the disastrous shadow diplomacy which was to follow. Graduate of an Australian Command and Staff College training program, Reinado also won the protection of arriving Australian military. On 1 June Reinado claimed to be loyal to President Gusmção and, upping the ante on Prime Minister Mari Alkatiri, stated he wouldn't surrender arms until the latter resigned. Gusmão and Ramos-Horta seemed to be falling in line, if they were not leading.

Although a number of observers identified rifts between and within the defense and police forces reaching back to their creation under UNTAET, the UN mission which administered East Timor up 
until independence, few publicly predicted a rebellion by the F-FDTL and bloody denouement of the traitorous PNTL at the hands of F-FDTL loyalists. Even so, as explained, the 33 Australian military trainers subsequently attached to F-FDTL cannot have been totally naïve, indeed, built links with individuals including the rebel leaders [8] Notably, the F-FDTL enjoyed the patronage of President Xanana Gusmão, especially in recruitment favoring easterners or Lorosae. The PNTL, under the control of interior minister, Rogerio Lobato, favored former Indonesian police, including its head Paulo Martins, with recruitment favoring the Loromono or those from the west of the country.

In late March violent incidents provoked by the Petitioner group in Dili led to the arrest of 48 including 8 members of the dismissed F-FDTL. On 28-29 April violent riots in Dili by hundreds of dismissed F-FDTL and supporters led to 5 dead and 60 injured in a clash with PNTL leading to some 100 houses burnt or damaged and with residents fleeing the city. This was one day after the Petitioner group rejected a government offer to establish a high level commission to investigate alleged regional discrimination. Meantime, with morale sapped and loyalties divided, the PNTL commenced to disintegrate with many members going over to the Petitioner group, and with others disarmed, leaving it virtually bereft of command structure. Even the police chief abandoned his post.

Just as Interior Minister Lobato threatened to arrest the rampaging protesters, so a government communiqué blamed Colimau 2000, a shadowy group of ex-guerrillas and disgruntled villagers led by Osario Leki, for hijacking the soldier's grievances. [9] Even so, the picture is undoubtedly more complex. As it would later emerge, opposition parties Partido Democratico (PD), led by Fernando “Lasama” Araujo, attracting support from Indonesian-educated youth along with 
westerners, and the conservative but marginal União Democratica Timorenses (UDT) were also in conversation with the Petitioner group. As discussed below, PD was especially well positioned to join in the push from the streets for political change along with armed gangs such as Colimau 2000, especially via its youth wing. [10]

By 5 May some 21,000 residents had fled Dili responding to rumors of an impending clash between military and police. They had good reason as, on 24 May, rebels led by Reinado fought loyalist military at their barracks at Taci Tolo. Violence irrupted again on 25 May with 10 unarmed PNTL officers gunned down in cold blood by F-FDTL loyalists as they left PNTL headquarters under the UN flag in a botched surrender agreement brokered by United Nations Police (UNPOL). Another 27 were left wounded, including two UNPOL officers in this shocking incident which prompted the Special Representative of the Secretary-General (SRSG), Hasegawa Sukehiro, to demand a full accounting by the RDTL government to determine responsibility and accountability.

Arguably, it was the decision of the Security Council to prematurely terminate the United Nations Office in East Timor (UNOTIL) mission (May 2005-August 2006) on the advice of Australia and Japan over the reservations of the Secretary-General, that allowed events to spin out of control; resulting in civil breakdown, some 30 deaths, some thousand houses destroyed, massive population dislocation; and the call for fresh military and international humanitarian intervention. Confronted with the prospect of a "failed state," as discussed below, consensus emerged in the Security Council to mandate a fresh UN mission. Notwithstanding the political risk involved in this fragile environment, priority was given to overseeing fresh elections. Just as elections in politically vulnerable settings should not be seen as a general panacea, however beloved of the international community, UNOTIL nevertheless began to prepare the country for both presidential and 
legislative elections. There was also recognition of the necessity to consummate the rebuilding of failed institutions in the attempt to achieve the kind of sustainable development necessary to break the cycle of unemployment and poverty that helped to fuel the violence. But as well recognized, the underlying cause of the crisis of 2006 lay with the security sector and the rebuilding of this sector was at the heart of Security Council discussions on the new mission. The crisis was not without domestic fallout. Amid much acrimony, including claims of coup d'etat, six weeks after a call for foreign intervention to stabilize the security situation, the elected RDTL Prime Minister, Mari Alkatiri, was obliged to step down.

\section{The Australian (Re)-Intervention}

With the security situation out of control, on 24 May 2006 the RDTL government formally requested security assistance from Australia, New Zealand and Malaysia. The legal basis of this assistance takes the form of “exchange of letters” between Canberra and Dili of 25 May. Reminiscent of its 1999 intervention in East Timor, Australia, which had pre-positioned ships off Timor island, was the first to respond and as the so-called "lead nation" assumed overall command of an International Stabilization Force (ISF) comprising some 2,500 Australian soldiers out of a total of 3,200 international forces, alongside 500 international police answering to UN command. Portugal subsequently sent a police detachment, the Guardia Nacional da Republica, (GNR) operating under its own mandate. With the arrival of an advance party of 150 Australian commandos on 25 May, the rules of engagement were hastily drawn up at a meeting at Dili airport involving the Australian Military Commander, the RDTL Foreign Minister, and the SRSG. On 26 May, following the signing of a formal Status of Forces Arrangement with Australia, the RDTL government handed over responsibility for security in Dili to Australian troops. It should be noted 
that Operation Astute - as it was known - did not operate under UN control, nor was it mandated by any Security Council resolution. The model would be that of the Australian-led Regional Assistance Mission to the Solomon Islands or RAMSI, a dual military-civilian stabilization force invited by the government of this Pacific country (but also criticized by some politicians for its heavy handedness).

But just as the government ordered the F-FDTL confined to barracks, the Australian military brazenly entered into liaison with Major Reinado, from his base in the central mountain town Maubisse. Far from arresting the military mutineer or members of the rebel Petitioners group, the Australian military (and media) shifted their attention to the task of reclaiming illegal arms from civilians, de-mobbed police, and other elements. Obviously reclaiming illegal arms caches was essential to restoring security and public confidence. Of particular concern was the provenance of a consignment of weapons earlier imported by the Minister of Interior. Many fingers pointed to the Minister, especially following the revelation of one Vicente Rai-Los Conceição, a former antiIndonesian guerrilla fighter, who claimed to have been given weapons by Lobato to defend Fretilin in forthcoming elections even by assassination, an act, he claimed, was endorsed by the then Prime Minister. With short-shrift to due procedure, on 19 July Lobato was apprehended, placed under house arrest by Australian military, and served a summons by the Dili District Court for “suspected involvement in providing arms illegally to civilians.” Damagingly as well, Lobato, also implicated the Prime Minister in this transaction. Even so, we confront the paradox that RaiLos - the accuser - participated with Reinado’s forces in the assault at Taci Tolo on 24 May. [11]

Notwithstanding the international military and police presence, violence flared with "gangs and thugs" - to use the words of the Australian force commander - engaging in widespread acts of 
violence, arson and intimidation, often against adversaries, perhaps better known to themselves than outsiders. Although such violence was often parlayed in the media - and by the President himself - as a fundamental ethnic clash between east and west, it was obvious that opponents of Fretilin, ranging from the Petitioner groups to the PD party and the usual culprits including proIndonesia martial arts gangs found the perfect pretext to settle scores. Fataluku-speaking migrants to Dili from the east became an easy target triggering an exodus; havenots lined up against haves, looting and burning seemingly at will, but selectively as well.

Even so, Australia faced down international condemnation for not protecting such sensitive government buildings as the offices of the Attorney General (where computers and court records were looted), along with ministries of development, agriculture, the national police headquarters, as well as rice warehouses. More astute observers began to read into this situation one of economic desperation on the part of urban unemployed. Added to that, a generation of children outside of formal education, also proved capable of being drawn into a cycle of violent behavior.

Needless to say, the state apparatus and public services were seriously disrupted in Dili, although services held up better in most of the districts. Shooting incidents, house burnings and even the stoning of relief workers by youths, continued through July 2006 . With 150,000 Internally Displaced Persons (IDPs) or some 15 percent of the country's population, squatting in some 57 mostly fringe urban camps, the humanitarian problem taken into hand by a range of UN and other international agencies also became one of dependency as IDPs refused or were too fearful of returning home. 
Australian insistence that it remain in charge of the security force outside of a Blue Helmet UN mission would later backfire, as Australians themselves subsequently became a target of hostility by supporters of victims of East Timorese casualties by Australian Defense Forces. Numbering 1,000 as of early 2007 (780 as of early 2008), on 8 April 2007, Australian Foreign Minister Alexander Downer announced that Australia might be willing to transfer ownership of the security force to UN control after the June 2007 legislative elections. Still, that did not transpire. Quite the reverse. As discussed below, following the 11 February 2008 assassination bid against newly sworn in President Jose Ramos-Horta, the incoming Rudd Labor government in Australia actually expanded Australia's force commitment by 250 (subsequently withdrawn in April 2008), while pledging a longer-term security commitment to the new nation. But even as the hunt proceeded for rebel holdouts, concerns of Australian interference or domination in the former Portuguese colony remained in the minds of many. [12]

Who, then, are the "gangs and thugs" referred to by the Australian military spokesperson? The object of one NGO study, Dili's gangs, numbering some hundreds of different bairo (village)-based youth groups, comprise diverse elements. Among them are a plethora of martial arts groups (15-20) with membership at around 20,000, and with origins going back to the pre-independence period. Other gangs of more recent origin appear to have emerged out of the unemployed and poverty stricken youth inside and outside of the IDP camps. Certain may be criminal elements loyal to gang bosses in some cases seeking to settle land disputes; certain may have targeted easterners, in large part owing to commercial rivalry, some may be purely opportunistic and some may be loosely in the pay of or aligned to political interests. Both Fretilin and opposition parties maintain links with gangs, just as certain are led by former resistance fighters. What is for sure is that, armed with crude and sometimes deadly weapons, alongside rocks, the gangs have been able to raise the costs 
of the international security presence, just as they destabilized and even paralyzed business, commerce, and government in the capital, and to a far lesser extent in certain of the districts. Even so, according to the NGO study, not all youth have resorted to violence and most youth groups actually seek in positive ways to unify their communities through collective activities. As voluntaristic groups, they operate below the level of more formalized NGOs. [13]

\section{Regime Change}

As intimated, one major outcome of the violence was the downfall of Prime Minister Alkatiri although not immediately the Fretilin government. Although the Canberra government went out of its way to avoid the charge of interfering in East Timor's domestic politics, differences emerged between Portugal and Australia especially over matters of state. Answering back to Australian Prime Minister John Howard’s charge of “poor governance” in East Timor, Portuguese Foreign Minister Diogo Freitas da Amaral stated, “We disagree with such declarations by foreign government.” [14] There is good reason to believe as well that, overthrowing the government was also the intention of those fomenting violence, namely the Petitioner groups and the opportunistic "gangs and thugs” that rampaged through Dili. Not all violence was random but certain carefully coordinated. We observe that, in one of the worst acts of violence, the 6-member family of the former Interior Minister Lobato were killed.

On 27 May violence by rampaging youths led the Prime Minister to publicly allege he was facing down a coup. Australian academic Tim Anderson also finds Australian backing for Alkatiri’s removal as crucial “not just for the personalities involved, but also for the country's economic development,” [15] in part a reference to the tense negotiations between Canberra and the Alkatiri 
government over the divisioning of Timor Sea oil revenues. As Chief Minister under UN administration and as DRTL Prime Minister, Mari Alkatiri led negotiations with the Canberra government over the Timor Sea Agreement, winning substantial concessions from a grudging Australia, although obliged to postpone legitimate international claims on maritime boundaries (just as Australia withdrew its accession to UN protocols on boundaries). As Prime Minister, Alkatiri also became the target of a concerted negative Australian media campaign, albeit successful as it turned out in the wake of the events of 2006, leading, inter alia to his resignation on 26 June.

Ironies of the situation abound. Days before the devastating violence, Alkatiri had been congratulated by the visiting World Bank President in Dili basically for adhering to Bank policies on lean government, fiscal frugality and pro-market policies. The DRTL under Alkatiri was no experiment in socialism. In fact, if the Fretilin majority government erred, as now appears apparent, it was because it consistently ran budget surpluses. To be sure, as Alkatiri asserts, his administration was literally reborn put of the ashes, and much was achieved in five short years.

On 30 May, Gusmão declared a 30-day “state of emergency” subsequently rolled on for another 30 days by the newly sworn-in Council of State, taking control of the army. The following day, the ministers of defense Roque Rodriques (1 June) and interior Rogerio Lobato (2 June) resigned with Jose Ramos-Horta (10 June) taking the defense portfolio with Alcino Barris assuming the post of Minister of Interior. This seemed appropriate as the two individuals in charge of security had obviously failed their respective offices, although it could also be said that the international community had also failed to safeguard the integrity of their offices. 
Meantime the street campaign to force the resignation of Prime Minister picked up steam. On 8 June 1,000 protestors demanded the dissolution of the Alkatiri government. The following day, Ramos-Horta called for investigation into allegations that Alkatiri had armed “death squads.” Typically, the RDTL Prime Minister and/or the ruling party was derided as, variously, arrogant, Marxist, and part of an out-of-touch Mozambique clique, leading many to conclude that Australia favored regime change. Other negative shibboleths repeated in the Australian press (notably the Murdoch flagship paper The Australian), harped upon the new nation's choice of Portuguese as an official (not national) language. Repeatedly, Alkatiri rebutted demands that he accept responsibility for the crisis. As he stated on 27 May, “I, the Prime Minister of Timor-Leste do maintain my previous statements. What is in motion is an attempt to stage a coup d'etat.” Identifying "foreign interests" behind the coup, he refused to be drawn. But he also made it clear that he was not referring to actions by the Indonesian government. In other statements, the Prime Minister elaborated upon three attempts by unnamed individuals and foreigners to stage a coup d'etat by, inter alia, seeking the complicity of the F-FDTL commander Brig Taur Matan Ruak. Having failed, the coup-makers then successfully sowed divisive ethnic-regional (Lorosae-Loromono) propaganda within the PNTL and between the PNLT and F-FDTL. [16] The "gangs and thugs" on the streets of Dili were less subtle in their propaganda, crudely deriding the Prime Minister as, variously, “communista,” Arab, Muslim, and even “terrorista.”

Just as the urban violence took on a political dimension, so tensions between the President and Prime Minister became public. Using unsubstantiated Australian ABC Four Corners television footing of 19 June as “evidence,” Gusmão directly implicated Alkatiri in the illegal formation of a "death squad” demanding he step down and face the courts. On 22 June, the President addressed a rally ending with a threat to resign if the Prime Minister himself did not. Constitutional issues were also at 
play, especially as the President has no unilateral right of dismissal of the Prime Minister given that both the Parliament and the Council of State must also be engaged. [17]

Yet, Alkatiri had the support of parliament and the Fretilin majority, even though - damagingly for Fretilin’s future electoral success - a "reformist” wing of the ruling party then emerged. On 25 June, further upping the ante, Ramos-Horta resigned. Responding to this brinksmanship and obviously isolated, the Prime Minister himself resigned on 26 June nobly, “assuming my own share of responsibility for the crisis affecting our country” [so as to avoid the resignation of the President]. On 27 June Alkatiri was summoned by prosecutors. [18]

Arriving from the east in large truck convoys, supporters of Fretilin were emotionally addressed by Alkatiri instructing them to desist from violence and prepare for the forthcoming elections. On 29 June 20,000 Fretilin supporters peacefully massed in the city before retiring. In the circumstances this was a magnanimous gesture as a Fretilin show of violence would undoubtedly have provoked a bloody clash or even civil war type of confrontation. But the contradiction cannot be lost, that while the Australian-led task force cosseted the anti-Fretilin rallies in the name of democratic rights, they did their best to quarantine the city from the arriving pro-Fretilin forces.

As later became transparent, certain of the anti-Alkatiri-anti-Fretilin rallies and demonstrations in Dili closely protected by Australian Task Force members were actually organized by members of the Petitioners group. According to Maj. Alves Tara, it was he and his National Front for Justice and Peace which rallied several thousand anti-Fretilin demonstrations in Dili in late June. He further upped the ante by threatening to return to Dili if Alkatiri failed to appear in court. [19] Still professing his innocence, Alkatiri temporized, claiming parliamentary immunity while rallying 
Fretilin support. Eventually, on 20 July, the former Prime Minister submitted to the jurisdiction of the Dili District Court.

With the swearing in of a new cabinet on 10 July (Second Constitutional Government), Fretilin was well represented with the post of foreign minister going to the Timorese ambassador to the UN, and Alkatiri rival, Jose Luis Guterres and with the new post of first Deputy Prime Minister awarded to Fretilin stalwart, Estanislau da Silva, with Rui de Araujo assuming the post of Second Deputy Prime Minister. Ending much speculation, Ramos-Horta (non Fretilin) was confirmed as Prime Minister, an appointment widely hailed in Canberra.

As the security situation stabilized, the Joint Task force sought different armed groups to surrender their weapons voluntarily. Major Reinado was the first faction leader to partially comply. Selfstyled “death squad” leader Rai-Los also handed over some weapons in a ceremony in Liquisa on 14 July. At the end of a two month amnesty period (late July), following an action by the GNR, Australian forces arrested Reinado and followers on possession of firearms charges. The Dili District Court indicted him on multiple charges including murder and embezzlement of firearms. Astonishingly, the rebel leader who precipitated the crisis and whose premeditated actions sparked the urban violence, followed rather than preceded the Interior Minister and Prime Minister to the Dili Court. The anti-Fretilin Youth for Justice and Peace group rallied in Dili protesting Reinado’s innocence. 


\section{UN Response to the Crisis of 2006}

While, as mentioned, on 24 May 2006 the RDTL government requested Australia, Malaysia, New Zealand and Portugal to send troops and police to help calm the situation, it was only on 26 May that the Security Council offered its blessing to Dili’s request, just as the following day the beleaguered UN mission in Dili announced that the majority of its staff would be withdrawn from the country. On 28 May, the SRSG requested international police force reinforcements. In the face of a mounting humanitarian crisis, especially relating to the spike in numbers of IDPs, a Danish national was appointed Humanitarian Coordinator for East Timor.

In May 2006, the Security Council (Resolution 1677) extended the UNOTIL mission for one month past its 30 May expiration. In June, under Resolution 1690, the UNOTIL mandate was further extended until 20 August with the request that, by 7 August, the Secretary-General provide the Council with a report on the UN role in East Timor following the expiration of UNOTIL's mandate. Obviously UNOTIL alone was not to blame for the unraveling of the security situation and the descent into chaos, but obviously it suffered problems of leadership, recruitment, local knowledge and vision. [20] The serving SRSG, Hasegawa, was not retained.

Following a request from the RDTL government, the UN established an independent special inquiry commission to review the incidents of late April and May 2006 as well as other events that contributed to the crisis. A three-person commission, led by Paulo Sergio Pinheiro of Brazil, was appointed on 28 June, with a brief to report by October. With Security Council approval, the Secretary-General's Special Envoy for Timor-Leste, Ian Martin (simultaneously head of the UN 
Human Rights Office in Nepal and former head of the UN mission in East Timor in 1999), was dispatched to Dili to assess the situation and report back.

Confronted by the prospect of a failed state, a consensus emerged within the international community that it had neglected to provide the new nation with adequate support for a sufficient time and acted too quickly in significantly reducing the UN presence on the ground. The so-called Core Group on East Timor (comprised of Australia, Brazil, New Zealand and Portugal - later expanded to include Malaysia and, from 2008, the Philippines) in addition to Security Council members France, Japan, the UK, and the US, acknowledged the need to establish a new, much more robust UN operation. As made clear on 13 June, the RDTL government expressed its wish for a UN peacekeeping force to replace the multinational force.

Then serving Timor-Leste Foreign Minister, Jose Ramos-Horta subsequently made it known that he wished the deployment of 800 international police for a period of five years. It is noteworthy that Ramos-Horta held back from seeking Timor-Leste’s inscription in the PBC as he may well have done. We can only speculate why this course was not followed; misplaced Timor-Leste confidence in their own ability to solve wide-ranging problems, or the weight of the Core Group and the interests of such nations as Australia inter alia privileged in Timor-Leste through its Status of Forces Arrangement, or Security Council disinterest alongside other pressing global issues

There were significant differences, however, regarding the shape of the future mission. While all agreed on the need for UN policing, differences emerged over the numbers required, with some arguing that a small number of high-quality police personnel would better meet the needs than personnel of many diverse national origins. Another point of contention was whether the 
operation should include a blue helmet military component under UN command or, as with the Australia military contingent, outside of UN command. Another issue was criticism on the part of the RDTL leadership as to the "heavy footprint" of previous UN missions and the dead hand of the UN bureaucracy, as shown by the huge diversity and inexperience of many international personnel. [21]

\section{The United Nations Integrated Mission in Timor-Leste (UNMIT)}

On 25 August 2006, acting upon the conclusions of the Ian Martin assessment mission, as well as input from the SRSG, the Security Council decided on the shape of a new UN mission. The United Nations Integrated Mission in Timor-Leste (UNMIT), East Timor's fifth UN mission since 1999 was established under Security Council Resolution 1704. On 5 February, the UN Secretary-General recommended that the mission be granted an additional 12 month extension. Officially the mission is concerned to "support stability, national reconciliation and democratic governance.” Additionally, it seeks to facilitate relief and recovery, and to aid justice and reconciliation. As discussed below, it also provided technical advice and support for the presidential and legislative elections held in 2007. Appointed in December 2006, Atul Khare, an Indian national, serves as SRSG. As of April 2008, the mission included 156 international staff, 382 national staff, some 1,608 UN Police along with 34 military liaison officers. UNMIT also seeks to reconstruct the Timorese police force (PNTL). Notionally, at least, UNMIT continues UN assistance with the Office of the Prosecutor General in resuming investigative functions of the former Serious Crimes Unit "with the aim of completing investigations into the serious human rights violations of 1999.” As an “Integrated” mission, UNMIT brings together the various UN agencies operating in East Timor "to maximize efficiency and impact.” [22] 
On 25 February 2008 Security Council (Resolution 1802) extended UNMIT's mandate for another 12 months. Deploring the attacks against the President and Prime Minister as "an attack on the legitimate institutions of the country” the Resolution sought UNMIT to intensify its work in strengthening the security sector including the PNTL. UNMIT also promised an internal investigation of the events of 11 February. Obviously such commitment is crucial to the rehabilitation of the nation, but we wonder whether such ad hoc-ism on the part of successive UN missions will ever raise capacity to a critical mass, such as envisioned by the PBC model.

\section{Independent Special Committee of Inquiry}

As mentioned, a UN Independent Special Commission Inquiry for Timor-Leste was mandated to establish the facts and circumstances relevant to the incidents of 28-29 April and 23-25 May 2006. It was also mandated to investigate related events or issues contributing to the crisis, to clarify responsibility for the events, and recommend measures of accountability for crimes and serious human rights violations specific to this time frame. Also, according to mandate, on 17 October 2006 the Commission Inquiry submitted its report to the National Parliament.

- The Crisis Cabinet and, in particular, the Prime Minister, Mari Alkatiri, was chided for failing to follow requisite legislative procedures in calling out the F-FDTL on 28 April.

- Concerning the events of 23 May, Major Reinado and his men were deemed "reasonably suspected” of committing crimes against life during an armed confrontation near Dili. In this 
regard, the then President (Xanana Gusmão) "should have shown more restraint and respect for institutional channels in communicating directly with Major Reinado after his desertion.”

- Specific to the events of 15 May, it held that the Chief of the Timor-Leste Defense Forces Taur Matan Ruak cannot be held responsible for the F-FDTL shooting of the unarmed PNTL officers, but concluded that he failed to exhaust all avenues to stop the confrontation.

- Notably, Minister of Interior Rogerio Lobato and Police Commander Paulo Martins "bypassed institutional procedures” by transferring weapons. Together, Lobato, Minister of Defense Roque Rodrigues, and Ruak "acted without legal authority” and should be "held accountable” for illegitimate transfer of weapons.

- Prime Minister Alkatiri was cited as failing to use his authority to denounce the weapons transfer, although no evidence was found leading to the recommendation that he be prosecuted, at least not before further investigation.

- President Xanana Gusmão was blamed for adding fuel to the fire by publicly claiming that the dismissal of the petitioners was unjust while lending credibility to their claims of regional discrimination.

- Generally, the Commission found "the fragility of various State institutions and the weakness of the rule of law were the underlying factors that contributed to the crisis.” [23] 
That is undoubtedly the crux of the matter, but the Commission is notably silent on the failings of international actors and the UN body itself. Although Alkatiri was personally cleared by the Commission of complicity in acts of illicit arms distribution, such as committed by Lobato, his opponents, both internal and external - and there were many - seized upon this innuendo to bring down the government. While Gusmão was directly censored by the UN Commission for inflaming community divisions at the height of the crisis, Ramos-Horta may not be totally immune from the same charge. Certainly, the Canberra government was not displeased by regime change in TimorLeste.

Incredibly, the individual at the center of allegations that forced Alkatiri to resign was only arrested in Dili in early October 2007, a year after the evidence came to light. This was Vincente de Conceição, alias Commander Rai-Los, determined by the UN Commission of having led 32 fighters in ambushes against Timorese soldiers killing at least nine. As determined, he was supplied with weapons by Lobato. As echoed in a high profile Australian television documentary, Rai-Los alleged that Alkatiri was personally involved in setting up a hit squad to eliminate political rivals. Even so, Fretilin has counter-claimed that Rai-Los carried a travel authorization letter carried by Gusmão. [24]

In any case, on 10 July 2006 Jose Ramos-Horta was sworn in as interim Prime Minister of the Second Constitutional government two weeks after Alkatiri resigned amid accusations that he was responsible for the violence. On his part Alkatiri remained indignant claiming to be a victim of a number of conspiracies on the part of unnamed international actors, including sections of the Australian media. 
As East Timor-watcher Joseph Nevins commented upon these findings, still in need of investigation was the role of the Catholic Church "which helped fan the flames that sparked anti-government (and by extension anti-eastern violence.” Added to that, as elaborated below, Gusmão’s “murky” role in communicating with the rebel Reinado outside of official channels also must be investigated. [25]

\section{Fretilin Government Failings and Fallout}

For want of capacity, as suggested, it was apparent that the nascent Fretilin administration proved incapable at project management, procurement and implementation, leaving spending gaps across the macro-economy. Where government spending and foreign investment could have helped to kick start the rural and urban economy, rising urban youth unemployment and frustration at the lack of development fueled popular anger. While such ineptness could be attributed to lack of experience and managerial capability on the part of the Alkatiri cabinet, the development and democracy discourse parlayed by international community, however well-intended, also obviously underestimated the specific historical, cultural and political setting of the fledgling nation.

If the Fretilin cabinet lacked managerial expertise and a dose of common sense, Alkatiri's other mistake was in his cabinet appointments. The choice of Rogerio Lobato (Minister of Interior), sentenced to seven and a half years imprisonment for distributing weapons to civilians, controversial from the outset as he was an unelected MP and had been convicted of diamond smuggling in Angola during his years in exile, may have been fatal for Timor-Leste. Even so, one wonders as to the efficacy of international advice and support in the so-called security sector which saw favoritism in both police and military recruitment among other anomalies. Such a bias in defense force recruitment favoring western recruits over easterners was in fact the pretext used by former Australia-trained Major Alfedo Reinado to defect in May 2006 joining an 
earlier group of rebels from the new nation's defense forces. Taking advice from the UN, Alkatiri was correct in cashiering the mutineers.

Neither was the security situation propitious for the Fretilin administration, notwithstanding international advice and assistance in this sector. Having dramatically staged a breakout from Dili's Becora prison on 30 August 2006 along with followers, Reinado defied all efforts to apprehend him, especially as he won a large following in the center-west of the country. Even so, he was contacted in his mountain hideout by members of Australian military forces, international media, and even leading RDTL government officials, including Xanana Gusmão and Jose Ramos-Horrta, raising questions about the nature of his immunity. Official tolerance only seems to have changed when, in February 2007, Reinado brazenly raided a police depot and captured weapons. Acting on orders from the RDTL President, Australian Special Forces mounted a botched raid on Reinado’s headquarters, leaving five of his supporters dead but with the renegade soldier evading capture. This led to violent demonstrations in the capital by supporters of Reinado. The UN in turn mounted an inquiry into the killings. Further urban violence flared when, on 7 March 2007, Lobato was sentenced by a panel of three international and one East Timorese judge to 7 years 6 months prison (appealed) for manslaughter and unlawfully using weapons. Earlier, charges against Alkatiri had been dropped, citing lack of evidence. As a result of the flare up of violence a number of foreign nations (Australia included) evacuated non-essential staff, just as the number of IDPs increased.

\section{The 2007 Elections}

It was against this uncertain backdrop that East Timor prepared for Presidential elections, with the first round held on 6 April 2007 and a runoff conducted on 9 May followed by parliamentary elections held on 
4 June 2007. For the international community, legitimacy had to flow from the ballot box, no matter the simmering security situation. The risks of igniting violence through the electoral process were all too evident. Reflecting local political culture, few of the major parties - Fretilin aside - could be said to be programmatic but, rather, drew upon the charisma of leadership just as they played to local, regional and sub-ethnic allegiances. The least programmatic and opportunist party was undoubtedly that hastily cobbled together by Gusmão, namely the Conselho Nacional de Reconstrução de Timor (CNRT) crudely - and controversially - adopting the acronym of the former resistance movement in the attempt to increase its appeal.

In the first round of the Presidential elections Jose Ramos-Horta (21.81 percent) narrowly defeated his PD rival Fernando “Lasama” Araujo (19.18 percent). Their Fretilin opponent Francisco Guterres gained 27.89 percent. In the second round, Ramos-Horta gained 69.18 percent of the vote with Guterres polling 30.82 percent. Regional loyalties also showed up in voting patterns whereby Fretilin made far stronger gains in areas of traditional resistance support, namely the east, while PD's gains were stronger in areas closer to the Indonesian border. Thus, the runner-up in the first round triumphed in the second round owing to a transfer of votes from PD loyalists. Lasama would subsequently be rewarded with the position of speaker of the parliament.

In the Legislative elections duly held in June 2007, Fretilin emerged as the single largest vote winner (29.01 percent) albeit short of an absolute majority with the CNRT gaining 24.1 percent, the Associação Social-Democrata Timorense (ASDT)/Partido Social Democrata (PSD) (15.75 percent) and PD (11.31 percent). Having been elected to the Presidency, Ramos-Horta invited the former President-turned-Prime Minister Gusmão to form the government at the head of his Parliamentary Majority Alliance (PMA) combining CNRT, ASDT/PSD and PD. The strongest party in this Alliance is the PSD with links with 
UDT, Fretilin’s historic rival. The defection from Fretilin of the current Deputy Prime Minister Jose Gutteres and supporters also worked in favor of Gusmão. Not all were happy with this outcome. Notably, Fretilin supporters launched a rash of house burnings but, overall, major violence was undoubtedly averted through the heavy international security and monitoring presence as much through pacts of non-violence entered into between the adversaries holding out some hope for future electoral contests.

Even so, the electoral process appeared as a prelude to a constitutional crisis. Rather than confirming legitimacy and socializing democratic norms, the outcome saw the former President and Prime Minister exchanging roles, in a situation where the party which gained the plurality of votes (Fretilin) being relegated to the opposition. Much turned upon interpretations of section 106 of the RDTL constitution (Portuguese version binding) whereby it is allowed that the Prime Minister shall be designated by the political party or alliance with parliamentary majority (before or after the election is not clarified) and appointed by the President after consultation with the political parties sitting in the national parliament. . Obviously there was no veto upon the party winning a narrow majority of the votes from taking office, demanded by Fretilin as a lawful right, just as there was no provision for a coalition of minority parties to automatically constitute the government. A Fretilin government would have been a weak government, but neither can it be said that the PMA government enjoys legitimacy across the board. Simply, the incoming President (Ramos-Horta) was kingmaker in facilitating the PMA government, although he may also have had later reservations.

It is understood that just prior to the 11 February 2008 Presidential assassination attempt,, as discussed below, Ramos-Horta had been in talks with political figures from across the spectrum, concerning the prospect of an early election, suggesting to this author a crisis of legitimacy barely masked in Dili. With good reason, Fretilin, the majority party, regards the process whereby the PMA government was installed 
as unconstitutional, although it since abandoned the idea of a legal challenge. Having hosed down sometimes explosive grassroots discontent at the virtual constitutional coup de etat exercised by RamosHorta, Fretilin initially boycotted the parliament. Even upon taking its place in the parliament, Fretilin continues to deride the so-called “defacto Gusmão-led PMA government.” At this writing, the PMA government is also beset with internal contradictions over alleged corruption, just as on 1 May 2008 ASDT entered into an agreement to work with Fretilin in future elections.

In another turn in this saga of recriminations, on 16 October 2007, Fretilin called for the resignation of the Timor-Leste Prosecutor-General Longuinas Monteiro asserting that he was in complicity in the ouster of the Fretilin government. Based on evidence presented to parliament in the form of an intercepted tape recorded telephone conversation, it is alleged that Monteiro met with Leandro Isaac, a confident of rebel leader Reinado, along with Herminigildo Pereira, a former chief-of-staff of Gusmao. More than that, although cited in the UN inquiry, Monteiro, declined to investigate Isaac as required. Fretilin therefore claims that, from the beginning, Monteiro has been conspiring to bring down Fretilin. [26]

The World Bank, the ADB and the major donors soon began to position themselves to influence the incoming PMA government especially as it sought to create - rhetorically at least - a more favorable environment for business and foreign investment. Land commodification might be one outcome, at least if the intractable problem of contested land title can be solved. The Fretilin preference for onshore LNG processing might also be sacrificed at Australian bidding. Gusmão already made known his preference to dip into the Petroleum Fund during the election campaign. The funds are not wanting, just as the Petroleum Fund is accruing several million dollars a month (far more than previous projections), but neither is deliverance guaranteed under the PMA government even if, as Alkatiri suggests, the new administration will basically follow the Fretilin administration’s leads. [27] 


\section{Trading Truth for Friendship}

As victims of crimes of humanity, bordering upon genocide in the views of some, East Timor rode a wave of international sympathy, just as international norms have shifted towards humanitarian intervention and the need for justice to be seen to be done. But, alongside Rwanda and the former Yugoslavia, Indonesia was granted a stay of time by the UN to build its own prosecutorial case against those accused of crimes in East Timor during the narrow period of 1999. But even when the UN-backed Special Court in Dili indicted a sheet of Indonesian military figures, including General Wiranto for “crimes against humanity,” (the socalled “Masters of Terror”), [28] Indonesia did not honor the extradition warrants. Gusmão even went as far as visiting Wiranto in Indonesia. In 2003, then DRTL Foreign Minister Ramos-Horta went as far as asserting that there was no need for an international tribunal because "Indonesia had changed.” [29]

Initially, Fretilin and Alkatiri distanced themselves from this highly pragmatic position such as to let Indonesia off the hook in the interests of international reconciliation. In fact, Alkatiri had been strident in calling for justice at a time when Indonesian President Megawati had been deflecting the judicial process in Jakarta. Alkatiri is not explicit, but the temptations to gain membership of the Association of Southeast Asian Nations (ASEAN) undoubtedly overrode his earlier reservations. While ASEAN continues to reinvent itself on human rights concerns (especially vis-à-vis fellow member Burma), ASEAN’s trademark contribution to regionalism remains its principle of "non-interference” in the internal affairs of member countries. One can only assume that the troika of DRTL President, Foreign Minister, and belatedly former Prime Minister were read the riot act on this tacit understanding.

The so-called Commission of Truth and Friendship (CTF), founded by Indonesia and East Timor in 2005, thus emerged as the key institutional mechanism whereby the two countries could seek to bury the past. 
Such a formula is all the more surprising especially as the international community had already invested millions of dollars and years of work in sponsoring the Comissção de Acolhimento、Verdade e Reconciliação de Timor-Leste, or the East Timor “Truth Commission” (CAVR) which handed down very specific recommendations on justice for the victims of crimes against humanity. [30] As suggested, the UN has consistently called for an International Tribunal to try the perpetrators of the crimes committed in East Timor. As recently as July 2007 the UN announced that it would not dignify the CTF owing to its amnesty provisions. As the UN spokesperson asserted on this occasion, “ the Organization cannot endorse or condone amnesties for genocide, crimes against humanity, war crimes or gross violations of human rights, nor should it do anything that might foster them.”

By joining elite consensus on reconciliation, even Fretilin was seen by many in Timor, from victims to activist NGOs, as out of touch, more the surprise that Alkatiri would actually defend the work of the CTF in Jakarta. Definitely the Indonesian people as much their leadership need to know the truth of events in East Timor but they could do worse than read the Indonesian language version of the CAVR report and act upon it.

\section{Presidential Assassination Bid of February 2008}

In yet another twist to the Reinado story, in the early morning of 11 February 2008 the rebel leader along with one of his band was shot dead by a F-FDTL guard in the compound of the Dili house of Ramos-Horta. Imprudently returning to the house from an early morning jog, the President was seriously wounded by enraged members of Reinado’s group who, apparently undetected by UN or Australian peacekeepers, had descended from the mountains to Dili during the night. Another party

of rebels led by Gastão Salsinha mounted a near simultaneous ambushed on the Prime Minister’s car. 
Slow to receive medical attention, the near assassination of the President again raised questions as to the co-ordination of UN police and F-FDTL. In any case, shot twice, Ramos-Horta only survived massive loss of blood thanks to expert medical care in Dili and surgery in an Australian hospital where he remained for almost three months before returning to Dili.

Internationally the attempt on the life of the RDTL president attracted widespread condemnation. Not only did the event further highlight the fragility of the security situation - a "state of siege" and curfew was brought down over most of Timor (only lifted on 22 April with the exception of one district) but, as mentioned, the Canberra government dispatched additional military and police. Many questions remained to be answered about this event, whether or not it was a coup de etat attempt, or assassination bid, or an act of revenge. Once recovered, Ramos-Horta lost no time in accusing “contacts” in both Australia (Reinado’s lawyer-lover) and Indonesia (non-official militialinks) behind his near assassination, vociferously denied by Indonesian government spokespersons. He also slammed UN forces for their slow response in coming to his rescue. Questions also remained as to the provenance of $\mathrm{A} \$ 800,000$ deposited into the Australian bank account of Reinado’s lover; the mysterious interview given by Reinado to a Jakarta television station, and the connection with Hercules Rozario Marcal, a Timor-born-Jakarta-based militia-gangland boss with close ties to Indonesian intelligence and received by Gusmão three weeks prior to the assassination attempt. We wonder as well as to the true import of a DVD recording made by Reinado - widely circulated in Dili - brazenly accusing Gusmão of having encouraged the original rebellion. According to veteran analyst John McBeth, in a comment upon the alleged Indonesia connection, the whole episode raises questions about the "shadowy figures" within the Jakarta military/intelligence establishment who still "haunt” Indonesian politics. [32] 
Whatever, it is clear that the President (and Prime Minister) were too trusting in dealing with the rebel-hero. Once again in mid-January, in the company of the Development Minister João Gonçalves, Ramos-Horta met up with Reinado in the mountain town of Maubisse and informed him that he intended to announce an amnesty on 20 May that would cover all crimes committed during the crisis of 2006. As mentioned, on 7 February Ramos-Horta hosted a meeting at his home to discuss the prospect of an early election.. All senior members of the Coalition along with the Fretilin opposition were present. The question of an amnesty for Reinado was also on the agenda. No formal consensus was arrived at during this meeting and further meetings were planned for 12 and 14 February. Obviously, with the denouement of 11 February, this timetable was derailed. In fact, on 10 February, secret negotiations between Ramos-Horta and Reinaldo continued via emissaries linked with a so-called Movement for Unity and Justice (MUNJ) group. It is now crystal clear that this shadow diplomacy with the highly unstable rebel leader came unstuck, just as the rebel-hero known for his unstable and erratic behavior - ordered his men to prepare for a visit to Ramos-Horta's house. The motive is subject to both rumor and investigation.

To be sure, as Australian academic Bob Boughton has written, Reinado was never a lone actor. Reinado, in this argument, took part in a coordinated movement to overthrow the elected Fretilin government. In so doing he won or gathered support from the second largest political party of the time, PD (led by Fernando Lasama Araujo), former supporters of integration with Indonesia certain including militia elements - disaffected veterans, and elements of the Catholic Church. In this Reinado gained appeal as a symbol of opposition to the so-perceived illegitimate Marxist Fretilin government. Reinado also proved to be serviceable to the electoral goals of PD especially as both drew support from the same population base west of Dili. We note that both Gusmão and Horta sought to block the arrest of Reinado, despite calls by UN investigators to bring them to book for a 
slate of crimes, just as PD support was crucial in sapping away at Fretilin electoral support. As Broughton asserts, "Under the 'guise' of engaging in dialogue with these dangerous anti-democratic forces, Gusmão and Ramos-Horta refused to move against them, in order to cement the votes they needed - first for Ramos-Horta to win the presidency, and then for Gusmão’s party to form an alliance including PD to take government.” [33]

The hunt by a joint military-police command - controversial in itself - for Gastão Salsinha and his surviving band of rebels continued until he surrendered on 29 April 2008, effectively bringing an end to the damaging two-year military rebellion, albeit not the many conspiracy stories surrounding the 11 February slaying of Reinado, the attack on the prime minister's car, and the near-fatal wounding of the president. Did Reinado seek to confront the president over the question of backsliding on amnesty? Was Reinado lured to the house only to be assassinated himself? Why, as Fretilin has queried, was the Prime Minister able to escape a close ambush mounted by professionals? Was the demise of Reinado an Australian-made solution - with or without Gusmão’s connivance, to avert a scenario whereby Fretilin would be brought back into government? [34]

Returning to Dili in April 2008, Ramos-Horta pledged to pardon 80 criminals involved in the violence of 2006, including Lobato. Such an act of reconciliation may have its merits but hardly brings justice or closure for these dastardly acts and outcomes. As the Australian government warns its citizens, "We advise you to reconsider your travel to East Timor at this time because of the fragile security situation and the risk of violent civil unrest. The situation could deteriorate without warning. There is a possibility that Australians and Australian interests may be especially targeted.” [35] 
Prudent advice but one wonders whether the country that was basically in charge of security and intelligence actually brought this situation down upon its head.

\section{Conclusions}

Was this then a failing state situation? Was East Timor becoming a Pacific Haiti in the worst possible sense? Could this situation have been averted with better international preparedness, or was this, as former Australian Prime Minister John Howard kept repeating, an egregious example of “bad governance?” [36] After all, should Timor-Leste be inscribed in the PBC at least in such a way as to support a new level of partnership (such as seems to be working in Sierra Leone) to avoid the worst excesses of international colonization?

We wonder as well about the politicization of ethnicity, the deliberate creation of east-west divisions in society by agent provocateurs and other actors that left many innocent victims. Certainly, as the Independent Special Committee of Inquiry concluded, the "fragility" of state institutions contributed to the crisis. And so too did leadership failure. Nevertheless, we cannot absolve international society including the United Nations. Crucially, Australia’s and Japan’s veto of mission extension flowing through to Security Council deliberations, was shortsighted. Looking further back, those individuals and nations responsible in the initial recruitment of the F-FDTL and the PNTL, simply failed the nation, as did certain of their trainers.

Undoubtedly, accountability for the events of 2006 will be necessary to create an atmosphere of trust and reconciliation for the future but, the need for full accountability for serious human rights violations and past crimes against humanity under the long Indonesian occupation is likely to prove 
just as important. As highlighted in the International Crisis Group Report, only a holistic approach to peacebuilding in East Timor can break the cycle of impunity necessary to safeguard the human security environment including the population displacement crisis.

Set back years by the violence of 2006, this author feels that only a deeply embedded and unencumbered UNMIT, or better still a longer term commitment as implied by the PBC, can lead East Timor out of its lingering crisis. This is especially the case as the new nation has the wherewithal for economic recovery - oil reserves amounting to over one billion dollars in escrow account - to see through sustainable development.

\section{Notes}

A highly abbreviated version of this article first appeared on www.http://Japanfocus.org/products/details/2722

[1] “Timor-Leste's Displacement Crisis,” International Crisis Group, Asia Report No.148, 31 March 2008. http://www.crisisgroup.org/home/index.cfm?id=5355>

[2] A/RES/60/180 of 30 December 2005.

[3] In March 2007 Japan's Ministry of Foreign Affairs hosted a symposium on peacebuilding including the possibilities of a PCB role in East Timor. It can only be surmised why, initially, 
Burundi and Sierra Leone alone met PCB inscription criteria. Can it be the case that the UN wished a success with these two cases rather than face another failure as with East Timor? Or, was the PCB unequal to the task owing to limitations imposed upon its foundation charter, not to mention such perennial problems as in raising the finances.

[4] Geoffrey C. Gunn and Reyko Huang, New Nation: United Nations Peacebuilding in East Timor, Tipographia Macau Hung Heng, Macau, 2006, p.2.

[5] Gunn and Huang, pp.155-74.

[6] On the culture of crime and corruption which continues to plague the current Gusmão administration, see Loro Horta, “The cost of crime in East Timor,"

http://WwW.atimes.com/atimes/Southeast_Asia/JD30Ae@1.html

[7] Rod Nixon, "The Crisis of Governance in New Subsistence States: The Case for Reorganising Local Capacities, Journal of Contemporary Asia, Vol.36, no.1, 2006, pp.75-101.

[8] Rees, Edward, “The UN’s failure to integrate Falintil veterans may cause East Timor to fail,” <http:/www.onlineopinion.com.au/view.asp?articel=666Author\%27\%29.bio>02 September 2003.\#”

[9] Lusa, 28 April 2006. 
[10] Carmela Baranowski, “Too many men with too many guns,” New Matilda, 12 July 2006, http://www.newmatilda.com

[11] John Martinkus, Interview with Mari Alkatiri, New Zealand Herald, 22 June 2006; "East Timor Speaks,” New Matilda, 28 June 2006 http://www.newmatilda.com

[12] See, for example, Richard Tanter, “The Crisis Beyond the Coup Attempt," http://www.japanfocus.org.products/details/2664

[13] The best analysis of Dili’s gangland is James Scambary, “A Survey of Gangs and Youth Groups in Dili, Timor-Leste,” A Report Commissioned by Australia’s Agency for International Development, AusAID, 15 September 2006.

<http://www.etan.org/etanpdf/2006/Report_Youth_Gangs_in_Dilipdf>

[14] Nick Beams, "Why Australia Wants "Regime Change in East Timor,” World Socialist Web Site, 30 May 2006. www.wsws.org. Of course one would not have to be a conspiracy theorist to peer through the opacity of official pronouncements, but the "dovetailing” of interests between Canberra and Reinado at this juncture seems just too fortuitous to be dismissed as pure chance. Finding such golden opportunities is precisely the line of work with which nation's intelligence services justify their existence. More the pity, perhaps, that the United Nations is not so well blessed in this area unless the PBC makes up for it.

[15] Anderson Tim , “East Timor after Alkatiri: nation or protectorate,” New Matilda, 26 June 2006 http://www.newmatilda.com 
[16] W. Wright, "East Timor: Internal Security, State of Siege and Emergency: A Note on the Constitutional Provisions and Internal Security Law of 2003,” East Timor Law Journal, 2006. WW. east timorlawjournal.org/ARTICLES/statesofsiege.html

[17] Lusa, 14 July 2006, "Ramos Horta Government gets "benefit of doubt” - dissident army officer."

[18] Jon Lamb, “East Timor: Deepening the Elite Crisis,” Green Left Weekly, 5 July 2006.

[19] Lusa, 28 June 2006 cited in Jon Lamb, “East Timor: Deepening the Elite Crisis.”

[20] UNOTIL

http://WWW.un.org/News/Press/docs/2005/sc8371/doc.htm

[21] Evidently this was a view shared by some members of the Core Group. See

http://Www. securitycouncilreport.org a site devoted to analysis and prediction of Security Council actions-in-the-making. One, albeit premature assessment of UNMISET is offered in Gunn and Huang (2006), pp.169-73.

[22] The official UNMIT website is http//:www.unmit.org

[23] Report of the United Nations Independent Commission of Inquiry for Timor-Leste http://www.ohchr.org/Documents/Countries/COITimorLeste.pdf

[24] Lindsay Murdoch, “Timor guerrilla held for assembly death squad,” The Age, 03/10/2007. 
[25] Joseph Nevins, “Timor-Leste in 2006: The End of the Post-Independence Honeymoon,” Asian Survey, Vol.XLVII, no.1, January/February 2007, p.166.

[26] “Fretilin calls on Ramos-Horta to sack prosecutor-general,” Fretilin Media Release, 16 October 2007.

[27] Tim Anderson. “Challenges for the Xanana Alliance,” Online Opinion: Australia’s e-journal of social and political debate, 17 October 2007 http://onlineopinion.com.au/view.asp?article=6428]

[28] Richard Tanter, Desmond Ball and Gerry van Klinken (eds.), Masters of Terror: Indonesia's Military and Violence in East Timor, Rowman \& Littlefield, Latham, MD, 2005.

[29] For a broad gauge study of the justice/reconciliation process in East Timor, see the author and Reyko Huang, “Reconciliation as State-building in East Timor,” Lusotopie, 2004, pp19-38.

[30] http://www.cavr-timorleste.org/

[31] “Timor-Leste: UN to boycott truth panel unless it bars amnesty for gross abuses,” UN News Centre, July 26, 2007 http://www.un/org/apps/news/Story.asp?NewsID=23340\&Cr=timor\&Cr1=

[32] John McBeth, “Timor-Leste: Moving beyond the shadow play,” The Straits Times (Singapore), 28 April 2008. 
[33] Bob Boughton, "Unraveling the East Timor Assassination Story: Republics rebel with friends in high places,” Japanfocus.org/products/details/2668 (The Australian, February 16, 2008.)

[34] For a rundown on dark plots and conspiracy theories see, Patrick O’Connor, "East Timor: Plot thickens as leader of alleged “coup” attempt surrenders,” World Socialist Web Site, 2 May 2008 http://WwW.wsws.org/articles/2008/may2008/etim-m02.shtml

[35] <http://www.smartraveller.gov.au/East Timor>

[36] For a lucid discussion on East Timor and failed state prospects, see James Cotton, “TimorLeste and the discourse of state failure,” Australian Journal of International Affairs, 61:4, December 2007, pp.455-470. Cotton argues that if East Timor is to be a "successful state" it is more likely to conform to Melanesian rather than Southeast Asian forms of functionality.

\section{List of Acronyms}

ASDT, Associação Social-Democrata Timorense, Timorese Social Democratic Association ASEAN, Association of Southeast Asian Nations

CAVR, Comissão de Acolhimento、Verdade e Reconciliação de Timor-Leste, Commission for Reception, Truth and Reconciliation in East Timor

CNRT, Conselho Nacional de Reconstrução do Timor, National Congress for the Reconstruction of Timor

CTF, Commission of Truth and Friendship 
F-FDTL, Falintil (Forcas Armada de Liberação Nacional de Timor-Lester)-Forcas de Defesas TimorLeste, Armed Forces for the National Liberation of Timor-Leste-Timor-Leste Defense Forces Fretilin, Frente Revolutionaria do Timor-Leste Independente, Revolutionary Front for an Independent East Timor

GDP, Gross Domestic Product

GNR, Guardia Nacional de Republica, National Republican Guard

IDP, Internally Displaced Persons

ISF, International Stabilization Force

LNG, Liquid Natural Gas

MUNJ, Movement for Unity and Justice

PD, Partido Democratico, Democratic Party

PBC, Peacebuilding Commission

PMA, Parliamentary Majority Alliance

PNTL, Policia Nacional de Timor-Leste, National Police of East Timor

PSD, Partido Social Democrata, Social Democratic Party

RAMSI, Regional Assistance Mission to the Solomons Islands

RDTL, Republica Democratica de Tinor-Leste, Democratic Republic of Timor-Leste

SRSG, Special Representative of the Secretary-General

UDT, União Democratica Timorenses, Timorese Democratic Union

UN, United Nations

UNAMET, United Nations Assistance Mission in East Timor

UNMISET, United Nations Support Mission in East Timor

UNMIT, United Nations Integrated Mission in East Timor

UNOTIL, United Nations Office in East Timor 
UNPOL, United Nations Police

UNTAET, United Nations Transitional Administration for East Timor 